\title{
Locating Diasporic Interspaces of Local Modernities: Malaysian Migrant Poetry Competition and Voices of the Displaced
}

\section{Abstract}

In this paper, I will refer to the Malaysian Migrant Worker and Refugee Poetry Competition and the subsequent collection of the selected entries entitled Voices of the Displaced. I will contend that this opportunity of showcasing the literary and cultural agency of traditionally peripheral migration in Malaysia is effectively instrumental in generating an alternative perspective in addressing the existing discourse of migration and diaspora. Therefore, I will propose that the notion of "local modernities," as professed by Bill Ashcroft, is an appropriate articulation in order to locate this contemporary cultural contingency. Consequently, I will attempt to argue that the emerging diasporic interspaces of local modernities in Malaysia are capable of not only creating shifting spaces and practices where participatory negotiation of sameness and difference can be sustained, but also of initiating a polylogue that represents the distinctive divergences.

Keywords: migration, diaspora, local modernities, Malaysia, migrant worker, refugee, migrant poetry competition, Voices of the Displaced

\section{Introduction}

Diaspora studies, including diasporic literary creations and scholarship, have widely broadened their scope during these contemporary times, encompassing not only diversely distinctive geographical locations and societal cultures but also highlighting the complex socio-economic and political contexts of multiple modes of migration, including the rise in refugees and asylum-seekers worldwide, which is rapidly coalescing into a global crisis. Writing within this context, in this article, I 
will focus on the peripheral migrants in Malaysia, particularly the migrant workers and refugees, and on their literary creations, mostly in different forms of poems. I will refer to the event of Malaysian Migrant Worker and Refugee Poetry Competition and the subsequent collection of the selected entries entitled Voices of the Displaced (2017) in order to contend that this opportunity of showcasing the literary and cultural agency of traditionally peripheral migration in Malaysia is effectively instrumental in generating an alternative perspective in addressing the existing discourse of migration and diaspora. Therefore, I will start with a brief introduction of the beginnings of this unique initiative of organizing Migrant Workers' Poetry Competition and then I will propose that the concept of local modernities is an appropriate articulation of locating this contemporary cultural contingency. Considering Ulrich Beck's proposition of the idea of "second modernity," Zygmunt Bauman's views on "liquid modernity," and Rosa María Rodríguez Magda's notion of "transmodernity," I will attempt to argue that eventually the notion of "local modernities," as articulated by Bill Ashcroft, is capable of not only creating shifting spaces and practices where participatory negotiation of sameness and difference can be sustained, but also of initiating a polylogue that represents the distinctive divergences.

Migrant Workers' Poetry Competition was first organized in 2014 in Singapore, in conjunction with the Singapore Writers Festival. Migrant workers comprise 38\% of Singapore's labor force, according to the 2019 report released by the Ministry of Manpower (MOM). These people are usually engaged in low-wage positions in construction, shipyards, and domestic works. The idea of organizing such a competition was mainly conceived by Shivaji Das, a travel writer-photographer, who was also working in a management consultancy firm in Singapore at the time. As Das, along with an NGO organization Transient Workers Count Too (TWC2), became acquainted with a center called Dibashram (day-shelter) that provides a space for these workers and runs a Bengali language newspaper entitled Banglar Kantha (Voice of Bengal), it inspired him to encourage the workers who assemble there to write poems from their own perspectives. Eventually, Ethos Books from Singapore published not just the competition, which attracts poems written in different languages including Bengali, Tamil, Mandarin, Tagalog, Bahasa Malaysia, Bahasa Indonesia, Cebuano, and others but also an anthology of poems entitled Me Migrant (2016), composed by the Bangladeshi migrant worker in Singapore Mohd Mukul Hossine and transcreated by the award- 
winning poet Cyril Wong. In the editorial note, Wong states that the poems have to be transcreated as they are written in "colloquial directness," expressing "essentially raw, but passionately honest versifications" (Wong). Following this volume, a bilingual anthology of Bengali poems and their English translations, entitled Migrant Tales: An Anthology of Poems by Migrant Bengali Poets in Singapore, was published in 2017 by a Bangladeshi publisher. Meanwhile, Singaporean filmmaker and writer Upneet Kaur-Nagpal directed a documentary Poets on Permits, 2016, featuring five migrant workers in Singapore — from Bangladesh, Philippines, India, China, and Indonesia — who share their lives through their own poems. Since 2014 these migrant workers/poets have become a key component of Singaporean literary and cultural scene and, in December 2018, the first Global Migrant Festival was held in Singapore. The festival brought poets, artists, economic migrants, refugees, academic experts, and community advocates from non-profit organizations together on the same platform which encourages "a broader, critical, human-centric perspectives and dialogues, in context of often vitriolic narratives that have dominated discussions on migration in Asia and across the world" (GMT). However, this initiative can, more importantly, provide a link between the Singaporeans and the other, the voiceless presence. Samuel Lee, who was a literature student at the NUS (National University of Singapore) when the first migrant poetry competition took place, interprets the effort in the following way: "I have not heard these voices before. But when [their] experience is put into words, you are able to empathize, you can put yourself in their shoes" (qtd. in Asher).

\section{Migrant Workers in Malaysia}

Malaysia has also become home to a substantial population of migrant workers in recent times. International Labour Organization (ILO), in its quarterly briefing note on Malaysia (January-June 2021), estimated that about 1.98 million regular migrant workers were working in Malaysia by September 2019 , constituting about $20 \%$ of the country's labor force (ILO). Malaysia is also overwhelmed with undocumented migrants, whose number was estimated to be about 2-4 million as of the end of 2018 (IOM). In addition to this reasonably large number of migrant workers, some 179,390 refugees and asylum-seekers were registered with UNHCR (United Nations High Commission for Refugees) in Malaysia as of end-August 2021. Most of them belong to different 
ethnicities from Myanmar, and the others are Pakistanis, Yemenis, Somalis, Syrians, Sri Lankans, Afghans, Iraqis, Palestinians, and others. Among them, more than 45,730 are children below the age of 18 (UNHCR). Malaysia has not yet ratified the 1951 Refugee Convention and its associated 1967 protocol, which agrees to the core principle of non-refoulement, asserting that refugees should not be returned to the country where they face serious threats to their lives and freedom.

These low-skilled migrant workers, who are mostly appointed to do the 3D jobs, meaning dirty, dangerous, and demeaning, are predominantly subjected to negative biases from the local populace. Malaysians barely give them a thought when they see them at work, except perhaps to complain that there are too many of them in towns and cities on holidays. In recent times, several incidents of serious labor rights abuses against migrant workers in Malaysia, including forced labor and human trafficking, have been recorded. The ILO report notes that female domestic workers are particularly vulnerable to exploitation and abuse. Moreover, political and public discourses repeatedly portray migrant workers as "a potential threat to national security and detrimental to the country's long-term social and economic development" (ILO). The recent Covid-19 pandemic has affected the migrant workers immensely. In addition to their loss of livelihood, they singularly suffer acutely from the widespread infection, mainly due to their overcrowded and unhygienic accommodation facilities. Malaysian government has also conducted multiple raids and detained thousands of undocumented migrants and refugees in an attempt to reduce the spread of Covid19. However, the government has eventually agreed to vaccinate the refugees and the undocumented migrants without detaining them on humanitarian grounds and urged the undocumented migrants to register under the Labour Recalibration Programme or the Repatriation Recalibration Programme (Mazwin et al.). Yet, the latest policy of requiring the undocumented migrants to be reported to the law enforcement authorities by the healthcare workers when they attend the Covid-19 vaccination centers, again raises concern (Babulal). However, the Health Ministry assures that there will be no action taken against undocumented migrants if they present themselves at vaccination centers (Arumugam and Bala Krishnan). In spite of the existing prejudices against the presence of migrant workers in Malaysia, there is no denying the fact that these migrant workers are contributing to the economic growth of the country by relieving labor shortages in some selected sectors of the economy. 


\section{Malaysian Migrant Worker and Refugee Poetry Competition}

The Malaysian Migrant Worker Poetry Competition started in 2015 as a part of the Cooler Lumpur Festival and back then had only seven participants. Since 2016 the contest has been organized independently and expanded by including Malaysia's refugee community. UNHCR in Kuala Lumpur supported the event and directed the Afghan refugees to the event in 2016, and the number of participants grew to 40. In 2017 there were 74 entries, and the competition was divided into junior (the youngest entrant was just six years old) and adult categories. Currently, the competition has two stages - the preliminaries and the finals. It has further expanded so that now the winners are chosen in three different categories - Junior, Refugees (Adult category), and Migrant Workers (Adult category). The competition has quickly established itself as one of the significant events in the cultural calendar of Malaysia. Since 2020, the competition is being organized online due to Covid-19 restrictions; however, the interest remains unabated. The finals include poetry recitals by the shortlisted migrant poets. There are no language requirements. Poems can be of any language besides English and Bahasa Malaysia, the national language of Malaysia. The competition receives entries written in Bengali, Urdu, Farsi, Bahasa Indonesia, Tagalog, Tamil, Sinhala, and the poems are later translated into English. All UNHCR cardholders, asylum seekers with an appointment card and a letter from UNHCR in Malaysia, and the migrant workers in Malaysia holding a Visitor's Pass or a Temporary Employment Pass are eligible to participate in the competition. The competition is sponsored by The High Commission of Canada in Malaysia, UNHCR Malaysia, The Good Shop, Thinkraw.asia, and Global Migrant Festival. The initiative is also supported by Malaysian academicians and literary personalities such as Carol Leon, Looi Siew Tiep, and Sharon Bakar, who also act as judges for the competitions (Migrant Workers). Responding to the organizers and volunteers' desire that these migrant workers and refugees have their works available in mainstream bookstores for the public to enjoy, Gerakbudaya Publishing Group in Malaysia published Voices of the Displaced in 2017, an anthology of the selected poems from the 2015-16 competition.

As stated earlier, I will interrogate the Malaysian Migrant Worker and Refugee Poetry Competition and the publication Voices of the Displaced in order to demonstrate how this competition platform 
has become effectively instrumental in generating an alternative perspective in the existing discourse of migration and diaspora. Even though the rising global migration is frequently labelled as a recent phenomenon, the practice of migration has always been a part of history since the beginning of mankind. Similarly, the word "Diaspora," which was "first used by Jewish scholars during the third century BCE in a Greek translation of The Bible" (Helly 3), has undergone many significant transformations in its meaning, concept, and application. Steven Vertovec rightly points out that the diversity of contemporary migratory patterns should not be studied only in terms of different ethnicities, but that discussions on the "super-diversity" of immigrant communities should include "differential immigration statuses and their concomitant entitlements and restrictions of rights, divergent labour market experiences, discrete gender and age profiles, patterns of spatial distribution, and mixed local area responses by service providers and residents" (1025). Therefore, I will first briefly explore the concept of different modernities and then proceed with the selected poems composed by the migrant workers and refugees in Malaysia in order to locate the emerging diasporic interspaces of local modernities.

\section{The Multiplicity of Modernities}

The concept of modernity, in the historical sense, identifies a radical reorientation of thoughts and ideas that pervaded the vast areas of politics, philosophy, science, and communication during the emergence of the European Enlightenment around the sixteenth century. It has been marked by the European voyages of discovery, the rise of capitalism, the beginnings of industrialization, urbanization, and political democracy, including the inception of the nation-state system. While referring to the human migratory movements, the era of modernity can even be located at the beginning of the fifteenth century. As the colonial expansion, transatlantic slavery, and indentured labor initiated the transnational flows, it also gradually engendered a corporeal hierarchy where the Europeans or the West assumed a superior position, capable of transforming the other, the primitive cultures into modern ones, according to Eurocentric ideologies.

As the aftermath of World War II, along with the rise of globalization and the technological and digital communication revolution since the 1980s, continue to impact different parts of the world, societies, and cultures, the stereotypical view of the singularity of modernity is questioned, and 
theories of multiple modernities have started to propagate. Eisenstadt proposes that the concept of multiple modernities is an appropriate approach to view and interpret the contemporary world. This idea transcends the "homogenizing and hegemonic assumptions" (Eisenstadt 1) of modernity solely as a Western construct. It also refutes the propositions, such as that liberal democracy would be the final form of human government as suggested by Francis Fukuyama (1992), or Samuel P. Huntington's (1996) hypothesis that future wars would not be fought between different states but between different cultures. According to Eisenstadt, the concept of modernity should be seen "as a story of continual constitution and reconstitution of a multiplicity of cultural programs" (2). He significantly notes that while certain systemic developments are materializing across a wide range of societies in terms of economic and political structure, urbanization, education, communication and even in individualistic orientations, such formations are also immensely influenced by "specific cultural premises, traditions, and historical experiences" (Eisenstadt 2). Consequently, the characteristics of modernity continue to assume variedly distinctive patterns and generate unique configurations of institutions and ideologies, not only in the historical sense but also within different cultural contexts.

While Charles Taylor, evoking the idea of cultural pluralism, asserts that one needs to examine the notions of cultural identities in its understanding of modernity, as "this difference crucially conditions the way in which they integrate the truly universal features of modernity" (33), Goankar, who proposes the term "alternative modernities," highlights the importance of distinguishing similarities and differences between social modernization and cultural modernity. A cultural theory of modernity, according to Goankar, not only evolves within a specific context of history, culture, and politics, leading to different outcomes, but also encounters certain processes of "creative adaptation" (16), which prompts oneself to question the present, as the present is perennially perceived as modern in every national, historical, and cultural configuration. Goankar's interpretation of creative adaptation is significant in the discussion of modernities as he argues that such a transformation unfolds the way "people 'make' themselves modern, as opposed to being 'made' modern by alien and impersonal forces" (16). Adopting a slightly different approach, Arif Dirlik argues that contemporary modernity assumes the form of a "local variant of a globalized capitalism," where "capitalist modernity, in its globalization, has had to interiorize cultural difference 
as part of its very constitution" (17). Therefore, agreeing with Christoph Senft, it is evident that the idea of modernity solely as a colonial and Eurocentric concept must be dismantled in order to uncover the entanglements lying outside "the parameters of hegemonic and ethnocentric discourses" (3). Consequently, since the last decade of the twentieth century, the idea of modernity has been interrogated and interpreted from various perspectives, as is evident in Ulrich Beck's proposal of "second modernity," Zygmunt Bauman's concept of "liquid modernity," and Rosa María Rodríguez Magda's notion of "transmodernity."

The idea of "second modernity," as proposed by Ulrich Beck, is not a simple, linear continuation of the existing discourse on modernities. Beck identifies a significant paradigmatic shift from modernity to "second modernity," which not only transmutes modernity from an industrial to reflexive phase but also transforms the industrial societies into risk society due to unforeseen secondary effects of modernity. Beck reminds us that we are all inhabiting a highly modern, yet a risk society, mainly due to the gradual rise in ethnic conflicts, threats of terrorism, internationalization of war, perils of environmental degradation and climate crisis, which he terms as manifestations of reflexive modernity. He states: "Risk is ambivalence. Being at risk is the way of being and ruling in the world of modernity; being at global risk is the human condition at the beginning of twenty-first century" (Beck 330). However, he also emphasizes that risks, in reality, are anticipations, and can become catastrophes only when translated into reality. Therefore, as he proposes that "risks exist in a permanent state of virtuality, and become 'topical' only to the extent that they are anticipated" (Beck 332), he asserts that risk is "a socially constructed phenomenon, in which some people have a greater capacity to define risks than others" (Beck 333). Hence, anticipation and construction of risks eventually unfolds the existing inequalities in modern society, which enables, as Beck witnesses, the "powerful actors to maximise risk for 'others', and minimise risk for "themselves'” (333). The increase of mass migration across the globe has certainly increased such risk as the boundaries between the locals and the foreigners, or, in other words, the strangers, who are hence suspicious, are gradually dismantling. Beck depicts this enforced intimacy in an ironic manner: "The distant other is becoming the inclusive other - not through mobility but through risk" (331). This fact of mobility also appropriately echoes Bauman's idea of fluidity as a suitable metaphor to signify the contemporary world of constant change and 
transformation, which, according to him, not only constructs a theme of liquid modernity but also yields dissimilar and discordant spaces, often engaging and clashing with each other.

In evoking the symbol of a fluid state of existence as a condition of liquid modernity, Bauman identifies two specific characteristics that can define the transitoriness of human migratory movements. He locates that fluids travel easily and do not maintain any particular fixed shape for a prolonged period of time, and therefore, "for them it is the flow of time that counts, more than the space they happen to occupy: that space, after all, they fill but 'for a moment'" (Bauman 2). For this reason, the temporary spaces, mostly generated and occupied by the steady stream of newly arrived migrants or outsiders, remain distant and different from the existing hegemonic spaces, inhabited by the locals or insiders. Similar to Beck's identification of anticipated risk, Bauman also distinguishes "the perceived horror of the dangers presented by the 'strangers at the gate"' (106). Bauman comprehends that even though both the spaces share the same world and are in communication, they rarely converse with each other. Efforts to keep the others at a distance are practiced more diligently when the strangers belong to a more marginalized group of migrants, such as the migrant workers and refugees, not just because their lived experiences and narratives are strikingly different but because of the existing stereotypical prejudices against such unwanted arrivals, as Georges Benko appropriately articulates: "There are Others who are still more Others than the Others, the foreigners" (25). However, the notion of transmodernity, while acknowledging the existing complexities of similarities and differences, offers a different approach.

The term transmodernity is first used by Rosa María Rodríguez Magda who argues that the prefix 'trans,' implying going beyond, appropriately signifies the age of globalization as an idea of transmodernity that could transcend the limits of modernity, which corresponds to the era of an industrial society. According to her, the notion of transmodernity is based on "the primacy of the transmissibility of information in real time, impregnated in transculturality, in which creation refers to transtextuality, and in which artistic innovation is thought as transavantgarde" (Rodríguez Magda). As she posits that transmodernity does not signify any rupture but induces a "dialectic synthesis of the modern thesis and the postmodern antithesis" (Rodríguez Magda), I propose that Ziauddin Sardar's interpretation of transmodernity is further appropriate in my discussion of Malaysian Migrant Worker and Refugee Poetry Competition. Sardar identifies transmodernity as 
carving out particular cultural spaces where "difference can exist as difference in terms of its own ideas, where cultures can be seen not just in terms of difference but also in terms of common ground" (34). Consequently, the concept of transmodernity, according to Sardar, produces a platform where "participatory negotiation of a plethora of (trans) modernities each answering to different histories" (33) can take place. Sardar approaches the idea of cultures as not existing in "splendid isolation" but "always interacting, synthesizing into new forms, evolving into new order" (34), so that, according to him, "each ethnic community, cultural identity, or faith group is capable of producing its own form of (trans)modernity based on its own norms, values, and worldviews" (33). Therefore, culture is seen as immensely flexible and expandable, capable of accommodating newness, domesticating the unfamiliar, and transforming itself continually.

Migrations in the twenty-first century are no longer confined within movements from the so-called third-world countries to the first-world countries, but various forms of transnational and transcultural exchanges and interactions could now be identified within different postcolonial nations. Bill Ashcroft, in his exploration of postcolonial modernities through literary analysis, professes that the concept of modernity should also be analyzed within postcolonial contexts, particularly against the contemporary issues of global power, global interaction, and cultural differences. Such an examination not only argues for the multiplicity of modernities but also re-evaluates the complex relationship between the hegemony of globalization and the agency of the other. Ashcroft prefers to use the term "transformations of modernity" to identify the multiple adaptations of modernity instead of using the term alternative, which implies propagating a different idea. Acknowledging the European provenance of the concept of modernity, which is predominantly associated with ideas of imperialism and capitalism, Ashcroft significantly locates modernity as a "culturally situated phenomenon" as well. However, he also points out that even though transnational and transcultural flows have widely pervaded imperial powers and colonial cultures, they did not essentially mutate into some uniform homogenization but have often been characterized by rhizomatic tendencies that, although they imply multiplicities, are still devoid of any hierarchical or centrifugal disposition. Therefore, modernities in this postcolonial predicament are transformative, "appropriating and transforming global cultural forms, global technologies and practices to local needs, beliefs and conditions" (Ashcroft). Thus, Ashcroft advocates the notion of "local" modernities, which is 
emancipated "to characterise the global, in their adaptation of the principles and technologies of modernity to local cultural conditions." Consequently, in the following section, I will focus on Malaysia's local cultural event of Migrant Worker and Refugee Poetry Competition and examine how such a unique initiative could sculpt diasporic interspaces of local modernities.

\section{Malaysian Migrant Worker and Refugee Poetry Competition and Voices of the Displaced}

As stated earlier, Malaysian Migrant Worker and Refugee Poetry Competition creates an open platform that convenes a broad spectrum of local Malaysians and migrants in Malaysia, who make their way through different predicaments and arrive from various locations around the world. The collection of poems Voices of the Displaced incorporates migrants/poets from eight countries in Asia and the Middle East (Bangladesh, Indonesia, Afghanistan, Pakistan, Myanmar, Philippines, Sri Lanka, and Syria) who share their thoughts and ideas in eleven languages, such as Bahasa Indonesia, Bengali, English, Hakha Chin, Mandarin, Persian, Punjabi, Tagalog, Tamil, and Urdu. The black-and-white cover art of an unmoored boat floating on water was conceived and designed by a stateless refugee Ali Rustom, who was born in Syria, displaced through Syria and Palestine, and is currently a refugee in Kuala Lumpur. The editors of the collection, in their sincere attempt to let the migrants and refugees speak on their behalf, display their intention of evoking "empathy and understanding of the Malaysian people towards the migrant and refugee population in Malaysia" (Premanathan and Han See xii). They appropriately point out that despite the differences in nationality, culture, religion, age, gender, language, and politics, "the common thread of human emotional experience is the same" (Premanathan and Han See xii). As I go through the poems included in the collection and also refer to some of the poems presented in subsequent competitions, I will not only examine their own unique and individual perceptions and lived experiences but also locate the evolving shift in vision, agency, and identity in generating diasporic interspaces of local modernities, since the initiative pertinently focuses on the innate curiosity: "What does it mean to be human from your perspective?" (Sardar 35).

The poems expose familiar diasporic themes such as longing for home, missing family and friends, ambition to provide for better opportunities, and expression of gratitude to the host country. The 
winner of the adult category of the 2016 competition, Tushar Mahmud Mithun from Bangladesh, compares his life as a migrant worker to a caged bird, longing to be free to return home:

I know that you are not keeping well,

Caged and with stifled breath,

Bird, you come back home. (Premanathan and Han See 69)

They also mourn for the loss of their near and dear ones, while being far away from home. On receiving the news of the death of his mother in Bangladesh, Ferari Murad grieves for her, while being alone in Malaysia:

Mother, I know you won't read this letter.

You won't float in salty tears

After thinking about me.

You are now faraway.

A place where the sun and the moon cross each other.

Still, I remember you, mother.

So many memories

And your face

Come to me in my sleep. (Premanathan and Han See 5)

Alika Nor Kholifa, who won second place in the Cooler Lumpur Migrant Poetry competition 2015, renews her vows to her loved ones at home of making her migrant worker's life a success on the first anniversary of her arrival in Kuala Lumpur:

It is heavy to wave a goodbye ...

Departure became difficult

Poverty separated us ...

I am not defeated

You need not feel guilty

I have yet to grasp the success of the world 
But it doesn't mean I do not have a future.

We are poor

But it won't stop the light of faith from shinning and strengthening us. (Premanathan and Han See

Another Indonesian in Malaysia, Wawan Sugianto, recalls his days of endless struggles both at home and away, yet he offers his gratitude to the country which has provided him with the means of sustaining an honest living:

I'm too tired to make a living

Caught in the unrelenting traffic in Jakarta

My joints are falling apart

Life is a struggle ...

Here, I am dependent

I struggle to earn a living

I continue living this life

We bemoan, and we cry, and we mourn the troubles we face here at home ...

Thank you, Malaysia

Because of you, my brother can still go to school

Because of you, the fire in our kitchen is still burning. (Premanathan and Han See 24-25)

However, the poems composed by the migrant workers and refugees in Malaysia are particularly significant because they spotlight certain critical issues which simultaneously address global predicaments and local concerns. They draw our attention to the challenges such as poverty or the threatening socio-political circumstances that force the migrants to flee their homes, the discriminatory treatment they face at work and within their new communities, and the deceit and betrayals they have to suffer from in search of some stability in their lives and in the quest of acquiring basic human dignity and peace. Refugees from Afghanistan refer to the endless war and genocide ravaging their homeland. Mehdi Rahman wishes that "[i]n our country, battle and Hazera genocide never existed” (Premanathan and Han See 59). Nasrullah Sharifi laments: “Sharifi' has 
abundant moans \& groans/ About the oppression of the Taliban of the time" (Premanathan and Han See 65). He identifies himself as: "I'm from Afghanistan, land of mourning/ Where I dip my bread in blood every morning" (Premanathan and Han See 65), sensitizing the local Malaysian audience of their tormented and traumatic lives, which has prompted them to leave their homes in search of homes elsewhere. The Syrian refugees in Malaysia similarly paint a dire picture of distress. Mohammad Hasan Al-Akraa wails:

\section{Oh World! \\ My land has perished!}

The independence of my land has been robbed! (Premanathan and Han See 119).

Young Afnan Belal, who is currently studying at a Syrian refugee school (Jasmine Ash Sham Alternative Education Centre) in Kuala Lumpur, recounts her horror: "Buzzing bullets heard... thousands of guns around me... every wall cracks... and the heart of fear, a panicked child..." ("The Finals"). Aghid Heshem Zriek, a student at the same school, pleads:

We were killed and burned and displaced and destroyed Our schools, our mosques and our Quran are burned This Damascus has been stolen ...

$$
\text { O world, }
$$

Do not kill the Sham

Consider, and consider... ("The Finals")

As these refugee-poets tentatively attempt to develop an inclusive space of belonging within the hegemonic space of the local community, they also unfold how they are being unwittingly dehumanized by the community and the mainstream media on a regular basis. Ten-year-old Abdullah Kasem Al-Yatim from Syria, the winner of the 2019 competition (junior category), relates his painful experience, which appropriately manifests the continued socially constructed phenomenon of an assumed and generalized risk of sharing a common space with a stranger, and highlights the modern configuration of inequality between the known and the unknown: 
I have had enough of being a Syrian refugee

Everyone started to get scared after hearing my name ...

I have had enough of being a ten years old man

I have had enough of being a child who lost his childhood.

Countries have agreed to my asylum

And humans agreed to hate me,

Even the word "human" was forbidden to me

I was called a refugee in all the headlines. ("The Finals")

As these ambivalent spaces of strangeness and fear remain a perpetual reality, these refugees, even after securing a provisional shelter in Malaysia, continue suffering from endless travails and uncertain futures. Mohammad Anwar from Afghanistan contemplates:

No home, no address, no company

No destination, no ship, no captain...

A settler is a broken heart, a broken wing

A settler is walking on an endless string. (Premanathan and Han See 62-63)

The third-place winner in the junior category of the 2016 competition recollects the day she left her home in Myanmar for Malaysia, hoping for a better life, and how anxiety and uncertainty continue to gnaw at her daily existence:

I was very young then, I didn't really know where we were going,

All I knew was that we were travelling to where my father and a better life were supposedly waiting,

Yet all these years I could sense the hardship faced by my parents as they grow older,

We are still deprived of our rights and our wish for a life much better, ...

I start to be concerned of how my life will eventually turn out to be,

And whether this dream of ours to resettle would ever become a reality. (Premanathan and Han

See 38-39) 
The platform of Malaysian Migrant Worker and Refugee Poetry Competition thus effectively mobilizes such voices of desperation, loss, and struggle for survival from different parts of the world, each responding to their unique histories and experiences. However, this distinctive cultural platform is particularly significant as it draws our attention to specific local issues as well, having global resonance. As already stated earlier, migrant workers in Malaysia, even though contributing to certain sectors of economy, are despised, suspected, exploited, and treated with contempt. The second-place award winner in the adult category of the 2016 competition, Figo Kurniawan, attempts to highlight the migrant workers' contribution to the growth of the nation and appeals to foster a sense of belongingness. He arrived in Malaysia from Indonesia in 2006 to work as a construction worker in Telok Gong, Port Klang, Selangor, and currently writes in different citizen journalism media, such as online bulletin Serantau and Kompasiana. His poem performed in the 2016 competition asserts:

$$
\begin{gathered}
\text { Migrant workers are not beggars, } \\
\text { Neither are we degenerates... } \\
\text { Buildings, shops, restaurants, }
\end{gathered}
$$

Plantations and factories are drenched with our sweat, Our evident struggles and contributions to the growth of this nation ...

Me and my countless brethren want only to live life like you.

To see us as human beings, aren't we all creations of God? (Premanathan and Han See 73)

Nasrikah, who arrived in Malaysia in 1997 to work as a domestic worker, focuses on even further marginalized migrant workers in Malaysia. The ILO quarterly briefing note on Malaysia (JanuaryJune 2021) points out that women domestic workers are particularly vulnerable to exploitation and abuse due to "the physical isolation of their workplaces, restrictions on movement and inadequate mechanisms established to ensure accountability of employers" (ILO). Nasrikah, who currently also acts as an advisor to Indonesian Migrant Workers' Community in Malaysia, namely Serantau, recounts her experiences at work: 
I call you master,

And you call me servant...

All my hours are forced into servitude to your family...

My body already drenched in sweat

At a time when many are still wrapped in slumber,

There are no hours in my work ...

But I still hear

The words stupid, idiot and being treated like a slave,

By people whose hearts are made of stone,

Who considers maids to be helpers...

However, if all the work is done by me alone, who exactly am I helping? (Premanathan and Han

See 78)

The empathy for each other that such a platform can inspire is significantly evident in the fact that the migrant workers participating in this competition do not forget their more unfortunate counterparts, those unable to utilize the platform due to their precarious predicament. I will here refer to two specific poems that raise concerns about the abuse and deceptions that these migrant workers face in the hands of unscrupulous employers and labor agencies that attempt to dispel the existing prejudice in Malaysia against these migrant workers, particularly the undocumented ones. Muhammad Mahfudz Zelani from Indonesia refers to Tenaga Kerja Indonesia (TKI) or "Indonesian Migrant Workers" in his poem titled "Masruroh." Indonesian migrant workers form the largest group of migrant workers in Malaysia, approximating around 690,659 (ILO) documented ones, and there is a large number of undocumented ones as well, most of whom are employed in low-skilled service and domestic sectors. However, they are not only exploited and abused at their workplaces but are also subjected to human trafficking, including forced labor and sexual exploitation. In a study on the Indonesian illegal workers' experiences in Malaysia, Ali Maksum and Surwandono note that the Malaysian public perceptions toward Indonesian migrant workers are mostly negative, and the female workers are particularly despised because they are being perceived as "slave" or 
"part-time employee/prostitutes." Mahfudz Zelani's poem portrays an imaginary Indonesian female migrant worker in Malaysia who has been deceived by an exploitative labor agent. He writes:

With determination and soaring desire, pursuing dreams, sky-high ... Willing to sacrifice for the sake of the family's future. Masruroh, you were called to the neighbour's country ... However, Masruroh, you've been fooled by an Agent with Satan's Mask. Masruroh, you're not working in a restaurant. Masruroh, you're not working as a janitor. But Masruroh, you're used as mere merchandise to satisfy men's sexual needs... (Premanathan and Han See 28).

Toward the end of the poem, Masruroh would eventually be arrested, imprisoned, and then deported, which is similar to the fate faced by many other migrant workers in Malaysia. However, the platform of this poetry competition has become instrumental in letting the local community know of these endless exploitations and oppressions, which often go unaddressed and unnoticed, exacerbating the contemptuous distance between the locals and migrant workers among them.

Figo Kurniawan, while participating again in the 2019 competition, focuses on the issues of PATI ( Pendatang Asing Tanpa Izin) or Workers without Permits in Malaysia. These migrant workers, secured mostly from the neighboring countries, such as Thailand and Indonesia, are smuggled into Malaysia by unscrupulous agents, who promise them to issue a permit against certain charges. However, once the payment is done, these illegal immigrants are deserted by the agents, and then they are regularly pursued by the immigration officials. However, even though these undocumented migrants face much disapproval from the local communities and the law-enforcing authorities alike, Figo Kurniawan's poem points out that most of them are actually being duped and deceived, and are in need of help:

“No, I'm not PATI! ...

I have already paid four thousand ringgit,

But haven't got a permit.

I was cheated, I was fooled"...

Not many people know

There was never anyone who understood 
They are victims, they are prey

That needs to be helped, not to be hunted ("The Finals").

Malaysian Migrant Worker and Refugee Poetry Competition thus unfolds the inherent complexities underlying diasporic and migratory movements, particularly with regard to such peripheral migrations. Conventional diasporic theories integrally tie diaspora with the notions of homeland and host land; however, these migrant workers and refugees in Malaysia, who undergo multiple displacements through poverty, hardship, violence, and discrimination, reveal an ambiguous and uncertain relationship with any particular geographical space at any particular time. Their connections and communications with the local communities also remain strained since most of the time they are being perceived as the dangerous other, and their vulnerabilities expose them to exploitation and deception of their superiors. However, the Malaysian Migrant Worker and Refugee Poetry Competition platform provides these peripheral migrants in Malaysia with a common and shared space, which eventually transmutes into a uniquely distinctive space where the comforting similarities are marked by remarkably different and heterogeneous histories and lived experiences. As discussed earlier, I, therefore, perceive this platform as manifesting rhizomatic characteristics, without any external, hierarchical force dominating and representing the voices of the strangers who converge on a common space. Moreover, as these migrant workers/refugees/poets articulate and initiate a polylogue of distinctive differences, Ashcroft's proposition of the transformative nature of modernities, generating in global interactions and cultural differences, re-evaluating the complex relationship between the hegemony of globalization and the agency of the other, proves to be accurate. The platform also recalls Gaonkar's proposition that such spaces are capable of inculcating alternative modernities where the occupants of the space could make themselves modern on their own terms and volition.

I will therefore conclude this paper by referring to one of the poems composed by Asiya Ishaq, a refugee-poet from Pakistan, who refuses to be labeled, either as an illegal immigrant or an asylum seeker or a trespasser, by the dominant nation-state of Malaysia, and questions through his poem: "What is an 'Identity'? / Is it really just a card covered in plastic with my picture?" (Premanathan and Han See 92). This disconcerting query alludes to the Eurocentric notion of modernity 
according to which perception of identity correlates with ideas of collective histories and common socio-cultural mores, and according to which divergent ethnicities and cultural differences could easily distinguish and mark someone as the other. However, as I have already examined, Malaysian Migrant Worker and Refugee Poetry Competition, while exposing the global predicaments of labor migration and refugees at large, adequately appropriates and articulates the local socio-cultural and political conditions through their own experiences as well. It also produces a space where participatory negotiations of sameness and difference are sustained through a continuing polylogue of emancipation. When a refugee/poet in Malaysia challenges the Eurocentric notion of modernity by questioning the incongruity of an imposed identity on the other and declares in front of a local audience that it is her very own shifting and drifting, traumatized and alienated self that is capable of constructing its own dynamic and diasporic identity, I can safely argue that this competition platform effectively transcends and transforms itself into fashioning distinctive diasporic interspaces of local modernities in Malaysia:

Am I really an identity-less refugee?

Look at me once more, and try to see...

I AM my identity.

Yes, I AM my identity. (Premanathan and Han See 93)

\section{Works Cited}

“The Finals - Malaysian Migrant Worker and Refugee Poetry Competition." 29 Sept. 2019, ELM Business School, HELP University, Kuala Lumpur.

Arumugam, Tharanya, and Dhesegaan Bala Krishnan. "No Action against Undocumented Migrants at Vaccination Centres." New Straits Times, 24 Sept. 2021, www.nst.com.my/news/nation/2021/09/730462/no-action-against-undocumented-migrantsvaccination-centres. Accessed 24 Sept. 2021.

Ashcroft, Bill. "Postcolonial Modernities." Kyiv-Mohyla Humanities Journal, vol. 1, 2014, kmhj.ukma.edu.ua/article/view/25707. Accessed 27 Sept. 2021. 
Asher, Saira. "Singapore's Construction Worker Poets." BBC News, 19 Mar. 2015, www.bbc.com/news/world-asia-31433806. Accessed 15 Sept. 2021.

Babulal, Veena. "MMA Dismayed by Need for PPV Staff to Report on Undocumented Migrants." New Straits Times, 24 Sept. 2021, www.nst.com.my/news/nation/2021/09/730421/mma-dismayedneed-ppv-staff-report-undocumented-migrants. Accessed 24 Sept. 2021.

Bauman, Zygmunt. Liquid Modernity. Polity Press, 2000.

Beck, Ulrich. "Living in the World Risk Society." Economy and Society, vol. 35, no. 3, Aug. 2006, pp. 329-45. Taylor \& Francis, doi:10.1080/03085140600844902.

Benko, Georges. Introduction: Modernity, Postmodernity, and Social Sciences. Space and Social Theory: Interpreting Modernity and Postmodernity, edited by Georges Benko and Ulf Strohmayer, Blackwell, 1997, pp. 1-44.

Dirlik, Arif. "Modernity as History: Post-Revolutionary China, Globalization and the Question of Modernity." Social History, vol. 27, no. 1, Jan. 2002, pp. 16-39. Taylor \& Francis, doi:10.1080/03071020110094183.

Eisenstadt, Shmuel N. "Multiple Modernities." Daedalus, vol. 129, no. 1, winter 2000, pp. 1-29, www.jstor.org/stable/20027613. Accessed 27 Sept. 2021.

Fukuyama, Francis. The End of History and the Last Man. Free Press, 1992.

Gaonkar, Dilip Parameshwar. "On Alternative Modernities.” Public Culture, vol. 11, no. 1, 1999, pp. 1-18. Duke University Press, doi: 10.1215/08992363-11-1-1.

Global Migrant Festival (GMT), www.globalmigrantfestival.com/. Accessed 15 Sept. 2021.

Helly, Denise. "Diaspora: History of an Idea." Muslim Diaspora: Gender, Culture and Identity, edited by Haideh Moghissi, Routledge, 2006, pp. 3-22.

Huntington, Samuel P. The Clash of Civilizations and the Remaking of the World Order. Simon and Schuster, 1996.

International Labour Organization (ILO). "Triangle in ASEAN Quarterly Briefing Note: Malaysia 
(January - June 2021)." www.ilo.org/wcmsp5/groups/public/---asia/---robangkok/documents/genericdocument/wcms_614381.pdf. Accessed 21 Sept. 2021.

International Organization for Migration (IOM). "Malaysia: Facts and Figures."

www.iom.int/countries/malaysia. Accessed 21 Sept. 2021.

Khokan, Zakir Hossain, and Monir Ahmod. Migrant Tales: An Anthology of Poems by Migrant Bengali Poets in Singapore. Translated by Debabrota Basu, Babui Prokashoni, 2017.

Maksum, Ali, and Surwandono. "Suffer to Survive: The Indonesian Illegal Workers Experiences in Malaysia and Japan." Journal of Social Research \& Policy, vol. 8, no. 1, July 2017, hi.umy.ac.id/wp-content/uploads/2019/01/Suffer-to-Survive-The-Indonesian-Illegal-WorkersExperiences-in-Malaysia-and-Japan-.pdf. Accessed 30 Nov. 2021.

Mazwin Nik Anis, et al. "Fear of Detention Overriding Fear of Getting Covid-19." The Star Online, 29 July 2021, www.thestar.com.my/news/nation/2021/07/29/fear-of-detention-overriding-fear-ofgetting-covid-19. Accessed 21 Sept. 2021.

Migrant Worker and Refugee Poetry Competition.

web.facebook.com/mymigrantpoetry?_rdc=1\&_rdr. Accessed 21 Sept. 2021.

Ministry of Manpower (MOM). "Report: Labour Force in Singapore 2019."

stats.mom.gov.sg/Pages/Labour-Force-In-Singapore-2019.aspx. Accessed 15 Sept. 2021.

Mohd Mukul Hossine. Me Migrant. Transcreated by Cyril Wong and translated by Fariha Imran and Farouk Ahammed, Ethos Books, 2016.

Poets on Permits. Directed by Upneet Kaur-Nagpal, Uptake Media, 2016.

Premanathan, Sharanya, and Tshiung Han See, editors. Voices of the Displaced: Poems from the Malaysian Migrant Poetry Competition 2015-2016. Gerakbudaya Enterprise, 2017.

Rodríguez Magda, Rosa María. "Transmodernity: A New Paradigm.” Translated by Jessica Aliaga Lavrijsen, 2011, transmodern-theory.blogspot.com/2017/05/transmodernity-new-paradigm.html. Accessed 27 Sept. 2021.

Sardar, Ziauddin. "Transmodernity: Art beyond Modernity and Multiculturalism.” Navigating 
Difference: Cultural Diversity and Audience Development, edited by Heather Maitland, Arts Council England, 2006, pp. 31-37.

Senft, Christoph. Contemporary Indian Writing in English between Global Fiction and Transmodern Historiography. Brill, 2016.

Taylor, Charles. "Two Theories of Modernity." The Hastings Centre Report, vol. 25. no. 2, April 1995, pp. 24-33. JSTOR, doi:10.2307/3562863.

United Nations High Commissioner for Refugees (UNHCR). "Figures at a Glance in Malaysia." www.unhcr.org/en-my/figures-at-a-glance-in-malaysia.html. Accessed 21 Sept. 2021.

Vertovec, Steven. "Super-diversity and Its Implications." Ethnic and Racial Studies, vol. 30, no. 6, 2007, pp. 1024-54. Taylor \& Francis, doi: 10.1080/01419870701599465.

Wong, Cyril. Editorial Note. Me Migrant. Transcreated by Cyril Wong and translated by Fariha Imran and Farouk Ahammed, Ethos Books, 2016.

\section{(c) (i) (3)}

Creative Commons Attribution-NonCommercial-NoDerivatives 4.0 International License 